\title{
Pengaruh Pergaulan Teman Sebaya Tehadap Motivasi Belajar
}

\author{
Ardiansyah $^{* 1}$ \\ Email: ardiansyah@ung.ac.id*1 \\ ${ }^{1}$ Program Studi Pendidikan Ekonomi, Fakultas Ekonomi, Universitas Negeri Gorontalo
}

Received: Agustus 2021

Accepted: November 2021

Online Published: Desember 2021

\begin{abstract}
The purpose of this study was to determine how peer association affects motivation to study at the State University of Gorontalo. The population in this study was all students who took the Introduction to Macroeconomics course in the odd semester of the 2020/2021 academic year at the Economics Education Study Program, Faculty of Economics, State University of Gorontalo. We used a technique called "saturated sampling" in this study. In other words, sample all populations. In this study, the independent variable is the association between peers and the dependent variable is students' learning motivation. The data analysis technique used is simple regression analysis. The results of this study indicate that peer association has a positive effect on learning motivation.
\end{abstract}

Keywords: Peer Association, Learning Motivation

\begin{abstract}
Abstrak
Tujuan dari penelitian ini adalah untuk mengetahui bagaimana pergaulan teman sebaya mempengaruhi motivasi belajar di Universitas Negeri Gorontalo. Populasi dalam penelitian ini adalah seluruh mahasiswa yang mengambil mata kuliah Pengantar Ekonomi Makro semester gasal tahun ajaran 2020/2021 di Program Studi Pendidikan Ekonomi Fakultas Ekonomi Universitas Negeri Gorontalo. Teknik sampling yaitu sampling jenuh. Dengan kata lain, sampel semua populasi. Dalam penelitian ini variabel bebasnya adalah hubungan teman sebaya dan variabel terikatnya adalah motivasi belajar siswa. Teknik analisis data yang digunakan adalah analisis regresi sederhana. Hasil penelitian ini menunjukkan bahwa peer group(kelompok teman sebaya) berpengaruh positif terhadap motivasi belajar.
\end{abstract}

Kata kunci: Pergaulan Teman Sebaya, Motivasi Belajar

\section{PENDAHULUAN}

Belajar merupakan proses untuk mendapatkan pengatahuan dan ilmu yang baru (Anderson et al., 1996; Inkpen, 1998; Kolb, 2002). Dari belajar kita akan menemukan banyak hal yang membuat pengatahuan ilmu kita bertambah. Kegiatan belajar tidak dapat dipashakan dari kehidupan manusia karena sepanjang hidup manusia akan selalu belajar terhadap hal-hal baru yang ditemuinya dalam kehidupannya. Proses belajar akan menghasilkan perubahan terhadap diri manusia. Sehingga tujuan hidup yang hendak dicapai yaitu keberhasilan dalam peningkatan hasil belajar dan siap berkompetisi serta bersaing dalam dunia kerja dapat dicapai (Kholisho, 2018) (Marfuatun, 2021). Di dalam proses belajar ada banyak aspek yang dapat menyebabkannya, aspek tersebut dapat berasal dari internal dan ekternal (Anderson et al., 1996; Luo et al., 2016; Miyawaki, 2006).

Aspek internal berkaitan dengan diri sendiri yang sumbernya berasal dari dalam diri sendiri seperti emosi, karakteristik belajar, motivasi, dll. Sedangkan aspek dari eksternal yang dapat mempengaruhi seseorang untuk belajar antara lain suasana belajar, teman sosial, fasilitas belajar, lingkungan belajar, dan lain-lain. Kedua aspek ini dapat saling mempengaruhi. Misalnya. motivasi vang rendah karena suasana sosial teman yang kurang mendukung dapat 


\section{Educatio: Jurnal IImu Kependidikan}

Vol. 16, No 2 Desember 2021, hal. 80-87

http://e-journal.hamzanwadi.ac.id/index.php/edc

e-ISSN: 2527-9998

DOI: $10.29408 /$ edc.v16i2.3959

menyebabkan perasaan rendah diri, sedangkan rendah diri yang rendah dapat menyebabkan kurangnya motivasi. Semangat dan motivasi belajar dari para mahasiswa merupakan salah satu indikator kualitas pembelajaran di kampus.

Motivasi merupakan suatu dorongan serta motif untuk belajar. Untuk meningkatkan gairah, semangat dan kesenangan dalam belajar pentingnya pemberian motivasi belajar (Heidig \& Clarebout, 2011; Kriegbaum et al., 2018; Seale et al., 2000). Motivasi dapat menumbuhkan kekuatan untuk mendorong individu dalam melakukan tugas-tugas guna mencapai tujuan mereka. Motivasi dibentuk oleh kekuatan baik di dalam maupun di luar individu. Karena perbedaan dalam nilai dan tujuan, mahasiswa yang tidak tertarik atau tidak merasakan relevansi dengan apa yang mereka pelajari dapat menjadi gangguan di dalam kelas. Mahasiswa membutuhkan motivasi untuk mencapai tujuan yang diinginkan; namun demikian, jika mahasiswa tidak memiliki dorongan untuk belajar, mereka tidak akan dapat mencapai apa yang diinginkan. Salah satu cara yang bisa dilakukan dalam peningkatan motivasi mahasiswa yaitu metode belajar yang digunakan (Maftuhin, 2021).

Dalam dunia pendidikan kampus, kita akan menjumpai berbagai karekteristik mahasiswa dalam menghadapi proses pembelajaran. Karakteristik itu dapat berupa motivasi yang berbeda tiap mahasiswa. Ada yang punya motivasi yang tinggi, sedang dan kurang. Rendahnya semangat belajar mahasiswa memicu penurunan kualitas lulusan perguruan tinggi. Banyak mahasiswa yang target utamanya hanyalah mendapatkan title sarjana saja dan bukan terfokus pada bagaimana menguasai ilmu pengetahuan banyak hal yang mempengaruhi motivasi belajar mahasiswa tersebut, salah satunya berasal dari lingkungan pergaulan teman sebaya. Mahasiswa pada umumnya akan menghabiskan sebagian waktunya berada di luar rumah, untuk bias berkumpul dengan teman kampus maupun teman sepermainannya. Bergaul dengan teman dapat mempengaruhi seseorang untuk dapat termotivasi dalam belajar (Chen et al., 2005; Roussel et al., 2011).

Pergaulan dengan teman sebaya dapat mengembangkan potensi yang dimiliki serta banyak beajar dari teman sebaya. Mereka akan menemukan pengatahuan-pengatahuan baru, informasi yang tidak meraka dapatkan di lingkungan keluarga. Pergaulan merupakan proses interaksi antara individu mahasiswa dengan yang lainnya dan bila berlangsung dengan jangka waktu tertentu maka akan membentuk jalinan persahabatan atau pertemanan (Obergriesser \& Stoeger, 2020). Pergaulan teman sebaya merupakan remaja atau anak-anak yang mempunyai tingkat kedewasaan atau usia yang hampir relatif sama oleh Santrock (2007: 55). Satu dari beberapa fungsi pada pergaulan teman sebaya yakni untuk mengembangkan hubungan sosial. Hubungan baik antar teman sebaya diperlukan untuk perkembangan sosial yang baik pada masa remaja.

Pergaulan mahasiswa sangat berpengaruh pada kepribadian mahasiswa. Teman dalam keseharian/bergaul dapat membentuk kepribadian mahasiswa. Kumpulan teman pergaulan dapat memotivasi banyak hal yang baik selama mahasiswa tersebut berada pada teman teman yang baik. Salah satu aspek terpenting dalam perkembangan mahasiswa adalah perkembangan kehidupan sosialnya. Mahasiswa belum mampu beradaptasi dengan pesatnya perubahan perkembangan sosialnya. Tugas perkembangan sosial mahasiswa merupakan tugas yang khas bagi mahasiswa. Mahasiswa sadar atau tidak bahwa mereka harus memenuhi tugas tersebut seperti tugas di kampus, namun di satu sisi tantangan mahasiswa untuk memenuhi tugas 


\section{Educatio: Jurnal IImu Kependidikan}

Vol. 16, No 2 Desember 2021, hal. 80-87

http://e-journal.hamzanwadi.ac.id/index.php/edc

e-ISSN: 2527-9998

DOI: 10.29408/edc.v16i2.3959

tersebut begitu besar sehingga mereka membutuhkan bantuan orang lain seperti teman sebaya atau teman sekelas, keluarga dan orang lain.

Teman sebaya merupakan faktor penting yang memiliki pengaruh kuat dalam kehidupan mahasiswa. Karena mahasiswa saat ini lebih banyak menghabiskan waktu dengan teman sebayanya dalam kehidupan sehari-hari. Selama periode mahasiswa, hubungan teman sebaya menjadi jauh lebih intens. Faktor-faktor yang mempengaruhi hubungan teman sebaya adalah peniruan, sugesti, dan simpati. Kesediaan untuk meniru orang lain merupakan faktor peniruan. Faktor sugesti adalah pengaruh psikologis, baik yang berasal dari diri sendiri maupun dari orang lain, yang dapat diterima tanpa kritik dari orang lain. Empati adalah perasaan tertarik pada orang lain (sartinyasin, 2015).

Teman sebaya sangat berpengaruh bagi tercapainya interaksi sesama mahasiswa, karena dari teman sebaya akan diperoleh informasi, dapat belajar kebudayaan, dapat belajar mobilitas sosial dan juga dapat belajar moral serta nilai nilai. Secara teori, ikatan teman sebaya memiliki arti penting yang signifikan bagi remaja karena mereka belajar tentang ikatan timbal balik terstruktur dari teman sebayanya. Melalui situasi konflik dengan remaja, anak mengejar konsep kejujuran dan keadilan. Mereka juga melakukan pembelajaran ekstensif terhadap minat dan perspektif teman sebaya untuk memfasilitasi integrasi mereka dalam aktivitas teman sebaya yang sedang berlangsung.

Fungsi pada kelompok teman sebaya menurut Santoso (1999: 85-87) adalan sebagai berikut berikut: 1). Mengajarkan kebudayaan, kelompok teman sebaya ini diajari tentang budaya setempat. Budaya kelompok sebaya ini diajarkan, seperti budaya lokasi itu. Misalnya, orang asing masuk ke Indonesia kemudian mengajarkan budaya Indonesia kepada rekan-rekan Indonesianya; 2) Menanamkan rasa mobilitas sosial. Perubahan status lainnya adalah mobilitas sosial. Ada masyarakat kelas menengah dan kelas bawah, misalnya (tingkat sosial). Istilah "mobilitas sosial" mengacu pada perpindahan orang dari kelas bawah ke kelas menengah. Jika seorang anak bergabung dengan kelompok teman sebaya dengan status sosial yang tinggi, ia akan merasa puas. Posisi sosial mereka akan meningkat ketika mereka mencapai status sosial yang tinggi. Karena identifikasi kelompoknya adalah identitasnya, seorang anak dalam kelompok sebaya dengan status sosial akan berintegrasi ke dalam satu bagian dari kelompoknya; 3) Membantu transisi ke posisi sosial baru. Anggota kelompok sebaya memiliki kesempatan untuk mengambil peran sosial baru. Anak-anak yang diajari menjadi pemimpin yang baik, misalnya; 4) Orang tua, guru, dan bahkan masyarakat umum dapat memperoleh manfaat dari kelompok sebaya. Kelompok sebaya dapat membantu instruktur dan orang tua memperoleh informasi tentang hubungan sosial seseorang, dan mahasiswa yang melakukannya dengan baik dapat dibandingkan dengan orang lain dalam kelompok. Peer group (kelompok teman sebaya) dalam masyarakat merupakan sumber informasi, dan jika salah satu anggota berhasil, maka anggota yang lain juga dapat berhasil dan peer group juga berhasil di mata masyarakat. 5) Anggota peer group dapat memperoleh rasa ketergantungan satu sama lain melalui rasa keberhasilan bersama. Seorang anak akan lebih mau berbagi dengan temantemannya karena dia memiliki lebih banyak teman mungkin untuk memahami dia dan kekhawatirannya. Anak-anak mengekspresikan emosi dan masalah yang tidak dapat mereka ungkapkan kepada orang tua atau guru mereka. Hal ini membuat ada ketergantungan terhadap teman sebaya lainnya. 
Karena mereka dapat merasakan rasa memiliki dalam kelompok sebaya ini, mereka saling mengandalkan satu sama lain; 6) Moralitas orang dewasa diajarkan melalui kelompok sebaya. Anggota kelompok sebaya bertindak dan berperilaku seperti orang dewasa untuk memperoleh stabilitas sosial dan mempersiapkan diri untuk masa dewasa. Mereka bertindak seperti orang dewasa, tetapi mereka menolak untuk dicap seperti itu. Mereka ingin menunjukkan bahwa mereka dapat menyelesaikan masalah tanpa bantuan orang lain; 7) Menggapai kebebasan sendiri. Di sini, kebebasan diartikan sebagai kemampuan untuk berpikir, bertindak, dan menemukan jati diri sendiri. Karena anggota lain dari kelompok itu memiliki minat dan keinginan yang sama. Berbeda dengan ketika anak-anak bergabung dengan orang dewasa, anak-anak akan merasa lebih sulit untuk menyuarakan ide atau tindakan mereka karena kedudukan orang dewasa selalu lebih tinggi di atas realitas teman sebayanya; 8) Belajar mengontrol tingkah laku. Seorang anak akan lebih mudah diawasi dalam kelompok sebaya karena perilaku setiap individu mencerminkan perilaku kelompok secara keseluruhan. Ini memudahkan orang tua dan instruktur untuk mengawasi anak-anak mereka.

Banyak hal yang akan didapatkan oleh para mahasiswa ketika mereka bersama-sama, mereka akan saling bertukar pikiran, saling memberikan umpan balik sehingga mereka merasa nyaman dan senang ketika mereka bersama-sama. Dalam pergaulan sosial mahasiswa akan memberikan damapak pada lingkungan sosial yang luas. Nilai-nilai sosial, perilaku, interaksi sosial, dan sebagainya menjadi cakupannya. Pengaruhnya akan memberikan dampak yang signifikan bagi setiap orang yang berada di lingkungan sosialnya. Berdasarkan uraian diatas dapat dipahami bahwa pergaulan mahasiswa memiliki peranan penting dalam membangkitkan semangat belajar mahasiswa. Oleh karena itu setiap mahasiswa hendaknya dapat menjaga keutuhan pertemanan sehingga mereka dapat saling memberikan feedback dan motivasi dalam belajar.

\section{METODE PENELITIAN}

Penelitian ini menerapkan pendekatan kuantitatif dengan menggunakan data kualitatif yang diangkakan. Penelitian ini termasuk dalam kategori penelitian ex-post facto, yang berfokus pada variabel-variabel yang peristiwanya terjadi setelah penelitian selesai. Observasi, dokumentasi, dan kuesioner digunakan untuk mengumpulkan data dalam penelitian ini. Sedangkan analisis regresi sederhana digunakan untuk menganalisis data. Teknik pengambilan sampel dengan menggunakan simple random sampling.

Jumlah responden dalam penelitian ini sebayak 77 orang mahasiswa yang diambil dari mahasiswa yang mengikuti perkuliahan pada matakuliah pengantar ekonomi makro semester ganjil tahun ajaran 2020/2021 di Prodi Pendidikan Ekonomi, Fakultas Ekonomi, Universitas Negeri Gorontalo. Variabel bebas dan variabel terikat merupakan dua variabel dalam penelitian ini. Variabel bebas adalah faktor yang mempengaruhi atau menyebabkan variabel terikat berubah atau terjadi. Sedangkan variabel terikat adalah variabel yang dipengaruhi atau merupakan hasil dari variabel bebas. Variabel dalam penelitian ini yaitu: 1) Variabel terikat (dependent variable): motivasi belajar (Y); dan 2) Variabel bebas (independent variable): pergaulan teman sebaya (X). Penelitian ini bersifat korelasi satu arah, yaitu mengkaji pengaruh pergaulan teman sebaya $(\mathrm{X})$ terhadap motivasi belajar $(\mathrm{Y})$ pada mahasiswa yang mengikuti perkuliahan pada matakuliah pengantar ekonomi makro di Universitas Negeri Gorontalo. 


\section{HASIL DAN PEMBAHASAN}

\section{Uji Normalitas}

Uji normalitas data Kolmogorof-Smirnov digunakan sebagai kriteria pengujian ini untuk menguji normalitas setiap data.

Tabel 1. Hasil uji normalitas

\begin{tabular}{c|c|c}
\hline \multicolumn{2}{c|}{$\begin{array}{c}\text { One-Sample Kolmogorov- } \\
\text { Smirnov Test }\end{array}$} & Keterangan \\
\hline $\begin{array}{c}\text { Asymp. Sig. (2- } \\
\text { tailed) }\end{array}$ & 0.279 & Normal \\
\hline
\end{tabular}

Berdasarkan tabel 1, pengujian normalitas yang dilakukan pada variable pergaulan teman sebaya dengan variable motivasi belajar dengan taraf signifiakan $\alpha=0,05$. Diperoleh sig. 0,279 dengan demikian dapat disimpulkan bahwa data berdistribisi normal karena nilai sig lebih besar dari $\alpha$ atau $(0,279>0.005)$.

\section{Uji linearitas}

Uji ini bertujuan untuk mengatahui hubungan yang linear atau tidak antara variable pergaulan teman sebaya dengan variable motivasi belajar. Pengujia linearitas data menggunakan SPSS yaitu Test of Linearity dengan taraf signifikan 0,005. Dua variable dikatakan mempunyai hubungan yang linear apabila nilai sig pada linearity kurang dari 0,005. Kesimpulan hasil uji linearitas dapat dilihat pada tabel dibawah ini .

Tabel 2. Hasil uji linearitas

\begin{tabular}{llll}
\hline Korelasi & F & Sig & Keterangan \\
\hline $\mathrm{XY}$ & 8.086 & 0.006 & Linear \\
\hline
\end{tabular}

Dari Hasil uji linearitas diperoleh nilai signifikansi 0,006 pada variable pergaulan teman sebaya dengan variable motivasi belajar. Karena nilai signifikansi 0.006 kurang dari 0.05 maka dapat disimpulkan bahwa terdapat hubungan yang linear anatara variable pergaulan teman sebaya dengan variable motivasi belajar.

\section{Uji Hipotesis}

Pengujian hipotesis dilakukan untuk mengatahui sejauh mana nilai hubungan atau pengaruh antara variable pergaulan teman sebaya $(\mathrm{X})$ dengan variable motivasi belajar $(\mathrm{Y})$ Hasil analisis dalam penelitian ini dapat dilihat pada table berikut. 


\begin{tabular}{|c|c|c|c|}
\hline $\begin{array}{l}\text { Yariabel } \\
\text { Independent }\end{array}$ & B & t- & Sig \\
\hline $\begin{array}{l}\text { Pergaulan } \\
\text { teman sebaya }\end{array}$ & 0.220 & 2.645 & 0.01 \\
\hline Konstanta & & & 48.414 \\
\hline F Hitung & & & 6.998 \\
\hline Sig F & & & 0.01 \\
\hline $\mathrm{R}^{2}$ & & & 0.085 \\
\hline $\mathrm{N}$ & & & 77 \\
\hline
\end{tabular}

Hasil analisis data bisa dilihat pada persamaan garis regresinya adalah $Y=\mathbf{4 8 . 4 1 4}+\mathbf{0 . 2 2 0}$ $\mathbf{X}$. Hasil perhitungan dengan menggunakan analisis varian untuk regresi diperoleh $\mathrm{F}$ hitung sebesar 6.998>F tabel 3.96 dengan sig $0.01<0.05$ yang berarti signifikan sehingga Ho ditolak dan Ha diterima. Hal ini menunjukkan ada pengaruh pergaulan teman terhadap motivasi belajar mahasiswa. Koefisien regresi untuk variabel motivasi belajar sebesar 2.645 bertanda positif yang artinya semakin tinggi tingat pergaulan teman sebaya maka akan semakin tinggi motivasi belajarnya Hasil analisis variable pergaulan teman sebaya terhadap variable motivasi belajar menunjukkan nilai t- Hitung sebesar 2.545>1.991 dengan nilai signifikan 0,05. Karena nilai signifikan $0,01<0,05$ dapat disimpulkan Ha diterima. Sehingga menunjukan bahwa pergauloan teman sebaya berpengaruh terhadap motivasi belajar Nilai Koefisien $\beta$ pada variable pergaualan teman sebaya sebesar 0.220 yang menandakan setiap penambahan tigkat variabel pergaulan teman sebaya sebesar satu persen (1\%) akan meningkatkan nilai variable motivasi belajar sebesar 0.220 persen. Sementara itu, nilai konstanta pada tabel adalah 48.414 yang berarti bahwa tanpa variabel pergaulan teman sebaya, nilai variabel motivasi belajar mahasiswa pada matakuliah pengantar ekonomi makro semester ganjil tahun ajaran 2020/2021 di Prodi Pendidikan Ekonomi, Fakultas Ekonomi, Universitas Negeri Gorontalo akan meningkat sebesar 48.414. Berdasarkan uji koefisien determinasi dapat diketahui bahwa besarnya pengaruh variable pergaulan teman sebaya terhadap motivasi belajar dapat dilihat dari nilai $\mathrm{R}$ square, yaitu sebesar 0.085 atau $8.5 \%$. Dengan demikian besarnya pengaruh variable pergaulan teman sebaya terhadap motivasi belajar pada mahasiswa prodi pendidikan ekonomi di Universitas Negeri Gorontalo sebesar $8.5 \%$, sedangkan $91.5 \%$ dipengaruhi oleh faktor-faktor lain yang tidak dikaji dalam penelitian ini.

Penelitian ini sejalan dengan penelitian yang dilakukan oleh Fitria dkk (2017) dan Yuliana dan Sarmidin (2019) yang menyatakan bahwa ada keterkaitan antara pergaulan teman sebaya dengan motivasi belajar. Intensitas interaksi mahasiswa dengan teman sebaya dan bersifat positf dapat meningkatkan motivasi belajar bagi mahasiswa. Motivasi belajar pada diri mahasiswa akan berpengaruh pada hasil belajar dan sebaliknya. Motivasi sangat penting dalam belajar. Motivasi adalah langkah awal dalam pembelajaran yang memotivasi mahasiswa untuk bergerak dan melakukan kegiatan belajar yang dapat mempengaruhi terhadap hasil belajar mahasiswa secara umum.

Keterlibatan teman sebaya dalam motivasi belajar akan mendorong dan mendukung teman untuk bisa menyelesaikan tugasnya. Saling memberi masukan, menyuarakan ide dan 
saling membantu. Dorongan dan dukungan teman sebaya dapat membantu mahasiswa belajar lebih efektif.

\section{SIMPULAN}

Berdasarkan hasil penelitian dapat disimpulkan bahwa terdapat pengaruh positif pergaulan teman sebaya dengan motivasi belajar mahasiswa pada matakuliah pengantar ekonomi makro semester ganjil tahun ajaran 2020/2021 di Prodi Pendidikan Ekonomi, Fakultas Ekonomi, Universitas Negeri Gorontalo. Dengan demikian, semakin tinggi variabel pergaulan teman sebaya maka akan semakin tinggi pula motivasi belajar mahasiswa. Hal ini juga berlaku untuk hal sebaliknya yaitu jika variabel pergulan teman sebaya rendah maka motivasi belajar mahasiswa juga akan rendah. Mahasiswa yang sering berinteraksi dalam kelompok teman sebaya yang beragam dan positif lebih memungkinkan untuk membangun motivasi belajar, yang mempengaruhi terhadap hasil belajar mereka.

\section{PERNYATAAN PENULIS}

Penulis menyatakan bahwa artikel ini belum pernah diterbitkan dalam jurnal manapun

\section{DAFTAR PUSTAKA}

Anderson, J. R., Reder, L. M., \& Simon, H. A. (1996). Situated learning and education1. Educational Researcher, 25(4), 5-11. https://doi.org/10.3102/0013189X025004005

Chen, J. F., Warden, C. A., \& Chang, H.-T. (2005). Motivators That Do Not Motivate: The Case of Chinese EFL Learners and the Influence of Culture on Motivation. TESOL Quarterly, 39(4), 609. https://doi.org/10.2307/3588524

Fitria, R. D., Rosra, M., \& Mayasari, S. (2017). Pengaruh Pergaulan Teman Sebaya Terhadap Motivasi Belajar Siswa. ALIBKIN (Jurnal Bimbingan Konseling), 5(1), 54-67.

Heidig, S., \& Clarebout, G. (2011). Do pedagogical agents make a difference to student motivation and learning? Educational Research Review, 6(1), 27-54. https://doi.org/10.1016/j.edurev.2010.07.004

Inkpen, A. (1998). Learning, knowledge acquisition, and strategic alliances. European Management Journal, 16(2), 223-229. https://doi.org/10.1016/S0263-2373(97)00090-X

Kholisho, Y. N., \& Marfuatun, M. (2018). Implementasi Kurikulum 2013 Pada SMK di Kabupaten Lombok Timur. Edumatic: Jurnal Pendidikan Informatika, 2(2), 120-127.

Kolb, A. Y. (2002). The Evolution of a Conversational Learning Space. Conversational Learning: An Experiential Approach to Knowledge Creation, 67-99.

Kriegbaum, K., Becker, N., \& Spinath, B. (2018). The relative importance of intelligence and motivation as predictors of school achievement: A meta-analysis. Educational Research Review, 25, 120-148. https://doi.org/10.1016/j.edurev.2018.10.001

Luo, Y., Wang, Z., Zhang, H., \& Chen, A. (2016). The Influence of Family Socio-economic Status on Learning Burnout in Adolescents: Mediating and Moderating Effects. Journal of Child and Family Studies, 25(7), 2111-2119. https://doi.org/10.1007/s10826-016-04002 
Maftuhin, M. (2021). Teams Games Tournament (TGT) Sebagai Metode dalam Peningkatan Motivasi dan Prestasi Belajar Matematika Siswa. Educatio, 16(1), 24-36.

Marfuatun, M., Kholisho, Y. N., \& Afifah, N. (2021). Pengaruh Lingkungan Keluarga Terhadap Pembentukan Tingkah Laku Anak. Educatio, 16(1), 71-79.

Miyawaki, K. (2006). The influence of the response-stimulus interval on implicit and explicit learning of stimulus sequence. Psychological Research, 70(4), 262-272. https://doi.org/10.1007/s00426-005-0216-y

Resti Yuliana, Sarmidin, H. A. (2019). Pengaruh Pergaulan Teman Sebaya Terhadap Motivasi Belajar Siswa. Jurnal Tarbiyah Dan Ilmu Pendidikan, 1, 127-131.

Roussel, P., Elliot, A. J., \& Feltman, R. (2011). The influence of achievement goals and social goals on help-seeking from peers in an academic context. Learning and Instruction, 21(3), 394-402. https://doi.org/10.1016/j.learninstruc.2010.05.003

Seale, J. K., Chapman, J., \& Davey, C. (2000). The influence of assessments on students' motivation to learn in a therapy degree course. Medical Education, 34(8), 614-621. https://doi.org/10.1046/j.1365-2923.2000.00528.x 